\title{
Probiotics and Intestinal Diseases
}

\author{
Philip Rosenstiel $^{\mathrm{a}}$ Eduard F. Stange ${ }^{\mathrm{b}}$ \\ ${ }^{a}$ Institute for Clinical Molecular Biology, Christian-Albrechts-University, University Hospital Schleswig-Holstein, Kiel, and \\ ${ }^{b}$ Division of Internal Medicine 1, Robert-Bosch-Krankenhaus, Stuttgart, Germany
}

The intestinal tract of higher metazoan organisms is colonized by an indigenous microflora that forms a complex ecosystem including both bacterial and fungal microorganisms [1]. A total number of $>1,000$ different species are estimated to be present in the human fecal flora at concentrations of up to $10^{12}$ viable microorganisms per gram stool [2]. It is widely accepted that enteric bacteria are of critical relevance not only to acute gastrointestinal infections but also to the pathophysiology of chronic inflammatory disorders like Crohn's disease or ulcerative colitis. It is well recognized that the close symbiotic relationship between host and resident microflora is an integral part of the homeostasis of intestinal physiology and is crucially involved in diverse processes, such as the metabolism of nutrients and organic substrates, as well as the development of intestinal epithelium, vasculature and lymphoid tissue [3].

This self-healing and self-regeneratory capacity of the balanced microflora (resilience phenomenon) seems to be defective in many gastrointestinal diseases, in which reduced microbial diversity is a constant characteristic, e.g. in inflammatory bowel diseases. We therefore think that intestinal inflammation (both during acute and chronic diseases) is promoted by a dysbalance of the microbial community caused by both host and microbial factors and that reconstitution of host micro- biota homeostasis may be a key factor to guarantee mucosal healing.

A promising option is the therapeutic application of probiotic strains of bacteria that may alter the observed dysbalance of the intestinal flora by both influencing the host side and the associated microbial communities [1]. Probiotics are defined as living microorganisms that - if taken in the appropriate dosage - may result in a health benefit for the human host organism. Several modes of action have been proposed, including antagonistic interactions with other bacterial strains and modification of host-protective immune responses [4]. Among the effects exerted by probiotics the direct competition with other bacteria through microcins, downregulation of inflammatory cytokines and induction of endogenous mucosal peptide antibiotics, most prominently defensins, appear to be the most important [5-7].

In clinical practice, the strongest evidence for the use of probiotics for gastrointestinal diseases has been presented for chronic inflammatory disorders, including pouchitis and ulcerative colitis [4]. In ulcerative colitis the probiotic strain Escherichia coli Nissle has been shown to be equivalent to mesalazine in maintaining remission. Probiotics, including lactobacilli and bifidobacteria, administered to children can reduce the incidence and duration of diarrhea, but the benefit may vary upon the na-

\section{KARGER}

Fax +41613061234

E-Mail karger@karger.ch

www.karger.com
(C) 2010 S. Karger AG, Basel

$0250-6807 / 10 / 0575-0027 \$ 26.00 / 0$

Accessible online at:

www.karger.com/anm
Philip Rosenstiel, MD

Institute for Clinical Molecular Biology

Christian-Albrechts-University, University Hospital Schleswig-Holstein

Schittenhelmstrasse 12, DE-24105 Kiel (Germany)

Tel. +49 431597 4268, Fax +49 431597 1842, E-Mail p.rosenstiel@mucosa.de 
ture of the condition. Other promising fields of therapy may include adult traveler's diarrhea, postinfectious irritable bowel syndrome and Helicobacter pylori infection. However, rigorous clinical studies are needed to completely understand the effects of probiotics in these disorders [4]. Despite promising data from animal studies, the effects of probiotics in radiation-induced enteritis in first clinical observations have been discouraging.

It must be noted that not all probiotics are created equal and that the term subsumes different commercially available preparations ranging from single defined strains (e.g. E. coli Nissle) to complex mixtures (e.g. VSL\#3). Future studies must also take into account that different preparations may have completely different therapeutic activities according to the site and modes of action. Thus, deeper insights into the genomic architec- ture and physiological capacities of the probiotic microorganisms will be needed to develop a rational therapeutic algorithm for each indication area.

We hypothesize that the specialty of gastroenterology may be profoundly affected by the ability to modify the host's gastrointestinal immune responses and gut-associated microbiota through the use of probiotics as rational therapies for gastrointestinal diseases.

\section{Disclosure Statement}

P.R. does not have any relationship to disclose.

E.S. has received honoraria for consulting on the topic of probiotics.

\section{References}

1 Kühbacher T, Ott SJ, Helwig U, Mimura T, Rizzello F, Kleessen B, Gionchetti P, Blaut M, Campieri M, Fölsch UR, Kamm MA, Schreiber S: Bacterial and fungal microbiota in relation to probiotic therapy (VSL\#3) in pouchitis. Gut 2006;55:833-841.

-2 Bäckhed F, Ley RE, Sonnenburg JL, Peterson DA, Gordon JI: Host-bacterial mutualism in the human intestine. Science 2005;307:19151920.

-3 Rakoff-Nahoum S, Paglino J, Eslami-Varzaneh F, Edberg S, Medzhitov R: Recognition of commensal microflora by toll-like receptors is required for intestinal homeostasis. Cell 2004;118:229-241.
4 Floch MH, Madsen KK, Jenkins DJ, Guandalini S, Katz JA, Onderdonk A, Walker WA, Fedorak RN, Camilleri M: Recommendations for probiotic use. J Clin Gastroenterol 2006;40:275-278.

5 Schlee M, Wehkamp J, Altenhoefer A, Oelschlaeger TA, Stange EF, Fellermann K: Induction of human $\beta$-defensin 2 by the probiotic Escherichia coli Nissle 1917 is mediated through flagellin. Infect Immun 2007;75: 2399-2407.
6 Wehkamp J, Harder J, Wehkamp K, Wehkamp-von Meissner B, Schlee M, Enders C, Sonnenborn U, Nuding S, Bengmark S, Fellermann K, Schröder JM, Stange EF: NF- $\mathrm{B}$ and AP-1-mediated induction of human $\beta$ defensin-2 in intestinal epithelial cells by Escherichia coli Nissle 1917: a novel effect of a probiotic bacterium. Infect Immun 2004; 72:5750-5758.

7 Möndel M, Schroeder BO, Zimmermann K, Huber H, Nuding S, Beisner J, Fellermann K, Stange EF, Wehkamp J: Probiotic E. coli treatment mediates antimicrobial human $\beta$ defensin synthesis and fecal excretion in humans. Mucosal Immunol 2009;2:166-172. 